(๑) Group of authors, 2021

UDC 616.141-089.48

DOI - https://doi.org/10.14300/mnnc.2021.16048

ISSN - 2073-8137

\title{
SUPERIOR VENA CAVA SYNDROME AFTER CORRECTION OF PARTIAL ANOMALOUS PULMONARY VENOUS CONNECTION
}

\author{
Zorinas A. ${ }^{1}$, Austys D. ${ }^{2}$, Aleknavichiene A. ${ }^{1}$, Janushauskas V. ${ }^{1}$, \\ Samalavichius R. S. ${ }^{1}$, Stukas R. ${ }^{2}$, Fatkulina N. ${ }^{2}$, Ruchinskas K. ${ }^{1}$ \\ ${ }^{1}$ Institute of Clinical Medicine, Faculty of Medicine, Vilnius University, Lithuania \\ 2 Institute of Health Sciences, Faculty of Medicine, \\ Vilnius University, Lithuania
}

\section{РАЗВИТИЕ СИНАРОМА ВЕРХНЕЙ ПОАОЙ ВЕНЫ ПОСАЕ ХИРУРГИЧЕСКОЙ КОРРЕКЦИИ ЧАСТИЧНОГО АНОМААЬНОГО АРЕНАЖА АЕГОЧНОЙ ВЕНЫ}

\author{
А. Зоринас ${ }^{1}$, А. Аустис ${ }^{2}$, А. Алекнавичене ', В. Янушаускас ${ }^{1}$, \\ Р. С. Самалавичюс ${ }^{1}$, Р. Стукас ${ }^{2}$, Н. Фаткулина ${ }^{2}$, К. Ручинскас ${ }^{1}$
${ }^{1}$ Институт кАинической меАицины МеАицинского факультета, ВиАьнюсский Университет, Аитва
2 Институт МеАицинских наук МеАицинского факультета, Ви^ьнюсский университет, Аитва

\begin{abstract}
Partial anomalous pulmonary venous connection (PAPVC) is an infrequent congenital heart defect. We report a case of rare complication following the correction of PAPVC in a 55 years-old male. On the fourth postoperative day after surgical correction of the mentioned congenital defect, our patient suddenly developed the superior vena cava (SVC) syndrome. Computed tomography revealed thrombosis of the upper part of the SVC. Following ineffective thrombolytic therapy, an urgent re-do surgery was performed. latrogenic narrowing of the SVC was found at its ostia to the right atrium. The SVC was fully occluded by thrombus up to the inflow of the innominate vein. The patient underwent successful thrombectomy and patch repair of the SVC.
\end{abstract}

Keywords: partial anomalous pulmonary venous connection, PAPVC, superior vena cava syndrome, complication, surgery

Частичный аномальный дренаж лёгочных вен (ЧАДЛВ) - редкий врожденный порок сердца. В представляемом клиническом наблюдении приводится случай осложнения, развившегося после хирургического лечения ЧАДЛВ у мужчины 55 лет. На четвертый день после хирургической коррекции ЧАДЛВ у пациента внезапно появилась симптоматика синдрома верхней полой вены (ВПВ). Компьютерная томография выявила тромбоз верхнего отдела ВПВ. После неэффективной тромболитической терапии была проведена экстренная повторная операция. Обнаружено ятрогенное сужение устья ВПВ. Вена была полностью закупорена тромбом до притока безымянной вены. Пациенту успешно выполнена тромбэктомия из верхней полой вены с последующей ангиопластикой синтетической заплатой.

Ключевые слова: частичное соединение аномальной легочной вены, синдром верхней полой вены, осложнения, операция

For citation: Zorinas A., Austys D., Aleknavichiene A., Janushauskas V., Samalavichius R. S., Stukas R., Fatkulina N., Ruchinskas K. SUPERIOR VENA CAVA SYNDROME AFTER CORRECTION OF PARTIAL ANOMALOUS PULMONARY VENOUS CONNECTION. Medical News of North Caucasus. 2021;16(2):206-208. DOI - https://doi.org/10.14300/mnnc.2021.16048

Для цитирования: Зоринас А., Аустис Д., Алекнавичене А., Янушаускас В., Самалавичюс Р. С., Стукас Р., ФатКУЛИНа Н., РУЧИНСКас К. РАЗВИТИЕ СИНДРОМА ВЕРХНЕЙ ПОЛОЙ ВЕНЫ ПОСЛЕ ХИРУРГИЧЕСКОЙ КОРРЕКЦИИ ЧАСТИЧНОГО АНОМАЛЬНОГОДРЕНАЖАЛЕГОЧНОЙВЕНЫ. МеДИцинСКИЙ вестник СеверногоКавказа. 2021;16(2):206208. DOI - https://doi.org/10.14300/mnnc.2021.16048

ASD - atrial septal defect

CBP - cardiopulmonary bypass

PAPVC - partial anomalous pulmonary venous connection
$\mathrm{Qp} / \mathrm{Qs}$ - ratio of total pulmonary to systemic blood flow

SV - sinus venosus

SVC - superior vena cava 
artial anomalous pulmonary venous connection (PAPVC) is a rare congenital defect which occurs in an adult population with a frequency of less than 1 percent [1]. In up to $90 \%$, it comes with the atrial septal defect (ASD) [2]. With respect to the type of PAPVC blood flow from anomalous pulmonary vein into the left atrium can be corrected through the ASD [3]. The superior vena cava (SVC) syndrome is a possible complication after surgery with cardiopulmonary bypass [4]. We present a case of the SVC syndrome after correction of PAPVC with ASD in a $\mathbf{5 5}$ years-old male.

Case presentation. A 55 years-old non-obese male six months before the admission presented with palpitations, dizziness, and shortness of breath during moderate physical activity. With the symptoms worsening, a cardiologist saw the patient. Transthoracic echocardiography revealed enlarged right ventricle and mild tricuspid regurgitation. No abnormalities were found in the left chambers of the heart. Computed tomography revealed PAPVC with inflow of the right upper pulmonary vein into the right atrium at the ostia of SVC with the sinus

A patient was scheduled for elective surgery. Before the operation, he underwent coronary angiography and catheterization of the right chambers of the heart. No significant pathology of coronary arteries was seen. Mean pulmonary arterial pressure was $16 \mathrm{mmHg}$ and the ratio of total pulmonary to systemic blood flow (Qp/Qs) was 1.4 (Figure) venosus (SV) ASD.

postoperative day, the patient was transferred from an intensive care unit to the ward, where he suddenly developed shortness of breath at rest, palpitations, and upper body edema with cyanosis. A cause of the SVC syndrome was confirmed by contrast computed tomography (Figure). The patient was transferred back to the intensive care unit, and thrombolytic therapy with intravenous heparin was initiated. The desired effect of thrombolytic therapy was not achieved in the following 72 hours, and urgent re-do surgery was performed. A CBP was established between the distal ascending aorta, innominate vein, and inferior vena cava. SVC was found narrowed at its ostia to the right atrium and fully occluded by thrombus up to the inflow of the innominate vein. Thrombectomy was performed. The narrowed SVC was corrected with a polytetrafluoroethylene patch. The patient was weaned from CBP and the operation was concluded uneventfully.

The further postoperative course was without complications. On the $13^{\text {th }}$ postoperative day, the patient was discharged with no symptoms. A month later, due to sick sinus syndrome, a permanent pacemaker was implanted. After four years follow up the patient was seen in the outpatient clinic. He had no symptoms, was fit and well.

Discussion. The prevalence of PAPVC in the adult population is less than 1 percent [1]. Presentation of PAPVC in adults in their sixth decade of life is infrequent. Such patients may present with symptoms of heart failure, palpitations, and pulmonary hypertension [5]. Routinely, symptomatic patients with

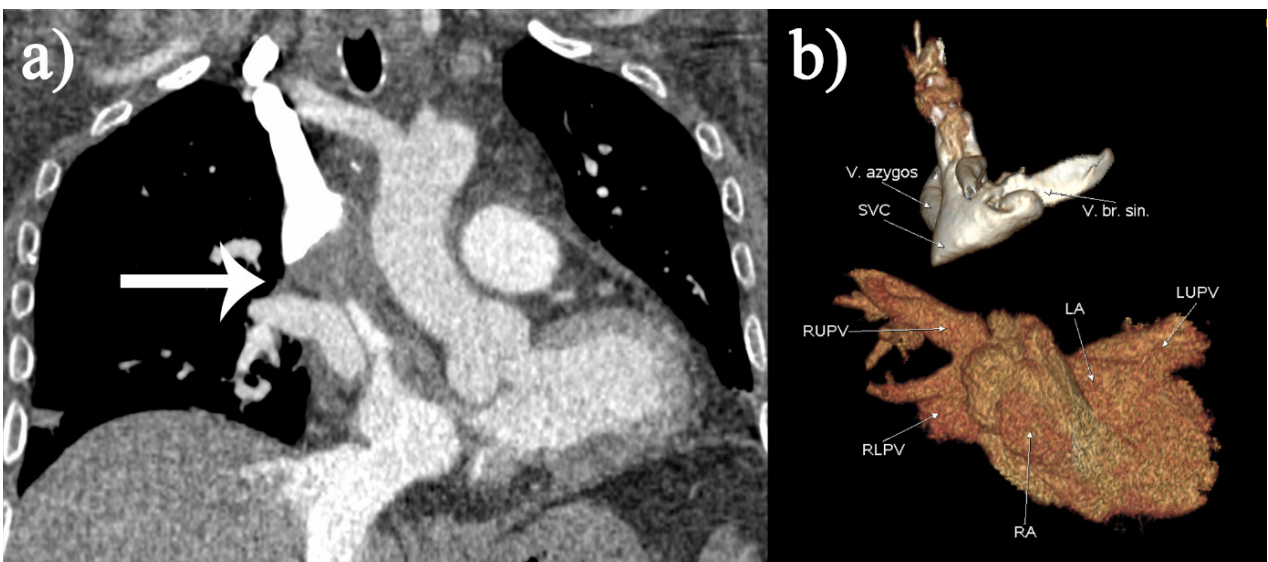
PAPVC and SV ASD with moderately elevated $\mathrm{Qp} /$ Qs ratio are treated surgically [6]. A surgical technique of PAPVC and SVC ASD repair in detail is described by Kouchoukos et al. [7]. However, this case report shows that complications such as SVC syndrome may occur. Other researchers state it may have various etiologies, including intrathoracic malignancies, mechanical obstruction by a retractor, malposition of the SVC

Fig. Computed tomography images: a) coronal plane and b) 3-dimensional reconstruction. The arrow on the image a) points to the obstruction of contrast media flow from SVC into RA. Legends of the image b): V. azygos - azygos vein, SVC - superior vena cava, V.br.sin. brachiocephalic vein, RUPV - right upper pulmonary vein, RLPV - right lower pulmonary vein, RA - right atrium, LA - left atrium, LUPV - left upper pulmonary vein mation on top of indwelling catheters or pacemaker wires $[9,10]$. In our case, the presentation of symptoms of the SVC syndrome

A surgical correction of PAPVC and SV ASD was performed under cardiopulmonary bypass (CBP) (established between the distal ascending aorta and both vena cava), with the patient moderately cooled and the heart fully arrested. The SVC was dissected from the pericardium towards the innominate vein. An autologous pericardial patch was used to repair PAPVC and ASD. Weaning from CBP was complicated due to bleeding from the SVC cannulation site. Additional multiple hemostatic sutures to the bleeding site of the SVC were placed, and the surgery was completed.

The early postoperative course was mildly complicated. Due to low cardiac output and peripheral vasodilation, the patient required small doses of inotropes. He also had an episode of atrial fibrillation, which was terminated with Amiodarone. On the fourth was not immediately after surgery. They developed suddenly on the third postoperative day. Therefore, the iatrogenic cause was not considered at that time. This led to an attempt at thrombolytic treatment, which proved to be ineffective. Computed tomography revealed the cause of the SVC syndrome, which was thrombosis of the SVC initiating from the cannulation site. Taking into account a performed surgery with additional hemostatic sutures at the site of cannulation the iatrogenic cause of the SVC syndrome was suspected. There were several possible triggers of it. A baffle «tunnel» from the ostia of the right upper pulmonary vein into ASD created an obstacle for blood flow from the SVC into the right atrium. However, as such «tunnels» are widely employed in PAPVC SV ASD surgery without complications [11], there must have been an additional cause. In our opinion, the primary fac- 
tor for initiation of thrombosis was additional hemostatic sutures used to control bleeding from the SVC at the cannulation site. This narrowed the SVC and significantly interfered with blood flow. The mechanical obstacles for blood flow in the SVC determined unsuccessful thromboIytic therapy. In the early postoperative period, the only effective treatment for our patient was a surgical repair.
Conclusions. In the surgical treatment of patients with partial anomalous pulmonary vein connection with sinus venosus atrial septal defect, to avoid thrombosis of the superior vena cava, care must be taken to elude surgical narrowing of the superior vena cava.

Disclosures: The authors declare no conflict of interest.

Acknowledgments. The authors would like to thank Jekaterina Cvetkova for the valuable comments and edition of this paper.

\section{References}

1. Ho M. L., Bhalla S., Bierhals A., Gutierrez F. MDCT of partial anomalous pulmonary venous return (PAPVR) in adults. J. Thorac. Imaging. 2009;24(2):89-95. https://doi.org/10.1097/RTI.0b013e318194c942

2. Broy C., Bennett S. Partial anomalous pulmonary venous return. Mil Med. 2008;173(6):523-4. https://doi.org/10.7205/milmed.173.6.523

3. Woestijne P. C., Verberkmoes N., Bogers A. J. Partial anomalous pulmonary venous connection (including scimitar syndrome). Multimed. Man. Cardiothorac. Surg. 2013;2013:mmt001. https://doi.org/10.1177/2150135112460250

4. Stewart R. D., Bailliard F., Kelle A. M., Backer C. L., Young L., Mavroudis C. Evolving surgical strategy for sinus venosus atrial septal defect: effect on sinus node function and late venous obstruction. Ann. Thorac. Surg. 2007;84(5):1651-1655. https://doi.org/10.1016/j.athoracsur.2007.04.130

5. Sahay S., Krasuski R. A., Tonelli A. R. Partial anomalous pulmonary venous connection and pulmonary arterial hypertension. Respirology. 2012;17(6):957-63 https://doi.org/10.1111/j.1440-1843.2012.02180x

6. Geva T., Van Praagh S. Anomalies of the Pulmonary Veins. In: Moss and Adams' Heart Disease in Infants, Children, and Adolescents: Including the Fetus and Young Adult, 7th ed, Lippincott Williams and Wilkins, Philadelphia, 2008.
7. Kouchoukos N. T., Blackstone E. H., Hanley F. L., Kirklin J. K.: Atrial Septal Defect and Partial Anomalous Pulmonary Venous Connection. In Kirklin/Barratt-Boyes cardiac surgery. 4th ed. Philadelphia, PA, Elsevier Saunders, 2012.

8. Adam W. A., Juan N. P., Geoffrey L. H. An unusual cause of intraoperative acute superior vena cava syndrome. Ann. Card. Anaesth. 2013;16:133-136. https://doi.org/10.4103/0971-9784.109770

9. Swetha M. C., Sudheer O. V., Murukesh S., Lakshmi K. Superior vena cava syndrome due to catheter related thrombus in a patient with a permanent pacemaker. Indian J. Anaesth. 2015; 59:758-760. https://doi.org/10.4103/0019-5049.170042

10. Lomivorotov V., Efremov S., Kirov M., Fominskiy E., Karaskov Al. Low cardiac output syndrome after cardiac surgery. Journal of Cardiothoracic and Vascular Anesthesia. 2016:31(1). https://doi.org/10.1053/j.jvca.2016.05.029

11. Chandra D. Gupta A., Nath R. K. Kazmi A. Grover V. Gupta V. K. Surgical management of anomalous pulmonary venous connection to the superior vena cava-early results. Indian Heart Journal. 2013;65(5):561-565. https://doi.org/10.1017/S1047951120002516

\section{About authors:}

Aleksejus Zorinas, DBiolSc, assistant professor; tel.: +37052365240; e-mail: aleksejus.zorinas@mf.vu.It

Donatas Austys, DBiolSc, assistant professor; tel.: +37052398738; e-mail: donatas.austys@mf.vu.It Aiste Aleknavichiene, student; tel.: +37063036631; e-mail: aistegrinkute@gmail.com Vilius Janushauskas, DBiolSc, assistant professor; tel.: +37052365307; e-mail: vilius.janusauskas@mf.vu.It Robertas Stasys Samalavichius, DBiolSc, professor; tel.: +37052365217; e-mail: stasys.samalavicius@mf.vu.It Rimantas Stukas, DBiolSc, professor; tel.: +37052398734; e-mail: rimantas.stukas@mf.vu.It Natalja Fatkulina, DBiolSc, professor; tel.: +37067400624, e-mail: Natalja.fatkulina@mf.vu.It Kęstutis Ruchinskas, DBiolSc, professor; tel.: +37052365149; e-mail: kestutis.rucinskas@mf.vu.It 